\title{
METODE TAKWIL NASR HAMID ABU ZAID (STUDI ATAS POTENSI TAFSIR ESOTERIK DALAM MERESPON PROBLEM TAFSIR ERA MODERN)
}

\author{
Salman Faris \\ Sekolah Tinggi Agama Islam Az Ziyadah \\ Jl. Masjid Al Husna No.79, Klender, Duren Sawit, RT.6/RW.9, Klender, Duren Sawit, Kota \\ Jakarta Timur, Daerah Khusus Ibukota Jakarta 13470 \\ Email: salismarshal@gmail.com
}

Abstract: $\quad$ Nasr Hamid Abu Zaid's Takwil Method (Study on the Potential of Esoteric Commentary in Responding to the Problem of Modern Era). The mechanism of the takwil method used by Abu Zaid in reading text is by approaching the text and trying to reveal the mysteries starting with the reading then the analytical level. The reading through the esoteric interpretation method with the Takwil device can contribute greatly in an effort to understand the Qur'an contextually, Abu Zaid carries two important terms in developing his interpretive approach to the Qur'an, namely al-Ma'na (meaning) and al-Maghza (Significance) which is the meaning represented by a text or what is represented by signs, while the significance of naming the relationship between a meaning and a person or a perception, a situation or something imaginable.

Keywords: esoteric commentary, Takwil, Nasr Hamid Abu Zaid, modern era

\begin{abstract}
Abstrak: Metode Takwil Nasr Hamid Abu Zaid (Studi Atas Potensi Tafsir Esoterik Dalam Merespon Problem Tafsir Era Modern). Adapun mekanisme metode takwil yang digunakan Abu Zaid dalam pembacaan teks yakni dengan mendekati teks dan berusaha mengungkapkan misteri-misterinya dimulai dengan pembacaan kemudian tingkat analitis. Pembacaan melalui metode tafsir esoteris dengan perangkat Takwil dapat memberikan kontribusi yang besar dalam upaya memahami Alquran secara kontekstual, Abu Zaid mengusung dua terma penting dalam mengembangkan pendekatan penafsirannya terhadap Alquran, yakni al-Ma'na (makna) dan al-Maghza (Signifikansi) makna merupakan makna yang direpresentasikan oleh sebuah teks atau apa yang direpresentasikan oleh tanda-tanda, sedangkan signifikansi menamai hubungan antara sebuah makna itu dan seseorang atau sebuah persepsi, situasi atau sesuatu yang dapat dibayangkan.
\end{abstract}

Kata Kunci: Tafsir Esoterik, Takwil, Nasr Hamid Abu Zaid, Era Modern 


\section{Pendahuluan}

Karakter bahasa yang digunakan Alquran adalah multiinterpretasi, yang memiliki arti berpeluang untuk ditafsirkan secara beragam. Sebuah riwayat yang disampaikan oleh Abu Nu'aim dan lainnya dari Ibn 'Abbas (w. 68H/689 M) menyatakan bahwa Alquran memiliki beberapa sisi dan makna ( $d z u$ al-wujuh). ${ }^{1}$ Penjelasan yang berasal dari Al-Suyuthi (849-911 H/1445-1505 M)

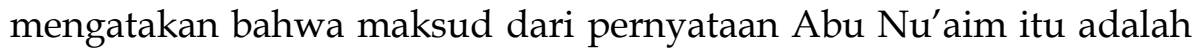
bahwa al-Qur'an memiliki dua sisi pemaknaan. Pertama, katakatanya terbuka bagi penakwilan. Kedua, sisi al-Qur'an berupa perintah, larangan, sugesti, halal, dan haram. ${ }^{2}$

Menurut sebagian Ulama, setiap ayat Alquran mengandung 60.000 pemahaman,33 bahkan -menurut ulama lain- 70.200 karena setiap kata (di dalamnya) adalah sebuah pengetahuan, dan kemudian jumlah itu dapat berlipat empat karena setiap kata mempunyai aspek lahir, bathin, awal dan akhir. ${ }^{4}$ Sebagai tambahan, Al-Biqa'i (w. 885 $\mathrm{H} / 1480 \mathrm{M})$ dengan indah menggambarkan Alquran dengan karakteristiknya di atas bagaikan intan yang setiap sudutnya memancarkan cahaya berbeda dengan yang terpancar dari sudutsudut lainnya. ${ }^{5}$ Dalam sudut pandang tertentu, justru itulah yang menjadikan Alquran berbeda dengan kitab-kitab konvensional dan sekaligus menjadikannya tetap aktual dan mudah diterapkan dalam berbagai kondisi dan tempat. ${ }^{6}$

1al-Zarkashi, al-Burban fi 'Ulum al-Qur'an (Beirut: Dar al-Ma'rifah, $1391 \mathrm{H}), 163$; lihat juga Jalaluddin al-Suyuti, al-Itgan fi Ulum al-Qur'an (Bairut: Dar Al-Fikr, t.t),h. 180.

2 al-Suyuti, al-Itqan fi Ulum al-Qur'an, h.180.

${ }^{3}$ Al-Qanuji,Abjad Al-Ulum Al-Wasi al-Marqum fi Bayan Ahwal al-Ulum (Bairut: Dar Al-Kutub Al-Ilmiyyah, 1978), h. 183.

${ }^{4}$ Muhammad 'Abd Al-'Azim Al-Zarqani, Manabil al-Irfan fi 'Ulum al-Qur'an (Beirut: Dar AlFikr, t.t.), h.23

${ }^{5}$ Muh. Quraish Shihab, Membumikan al-Qur'an (Bandung: Mizan, 1992), h. 16.

6 Sebuah penelitian tentang keunikan bahasa Arab, bahasa yang digunakan Alquran,telah dilakukan M. Quraish Shihab, Mujizat al-Qur'an, (Bandung: Mizan, 1997). Di dalamnya, umpamanya, ia mengutip pendapat De' Hammaer yang mengemukakan bahwa kata yang menunjukkan unta dan keadaannya ditemukan sebanyak 5.644 kata. Kekayaan makna yang dimuat kata-kata dalam al-Qur'an mendorong pakar 'Ulumul Qur'an meletakkan sebuah cabang disiplin ilmu bernama $A l-W u j u h$ Wa Al-Naza'ir. Menurut Ibn Al-Jauzi, wujub dan naza'ir adalah satu kata yang diulang di beberapa tempat dalam Alqur'an, tetapi maknanya berbeda-beda. Kata 
Diantara konsekuensi karakter Alquran di atas adalah kemunculan beragam produk penafsiran yang kini sudah dikoleksi dalam kitab-kitab Tafsir,7 Meskipun itu bukan satu-satunya faktor yang memunculkan keragaman tersebut. 8 Prestasi para mufasir dalam menghasilkan karya Tafsir dilukiskan dengan baik oleh AlSubuki (683-756 H/1284-1355 M). Ia berkata, "Seandainya meletakkan kitab-kitab Tafsir di samping Alquran, Anda akan berada di hadapan bukit kitab Tafsir yang menjulang tinggi." 9

Secara umum dapat dikatakan bahwa kitab-kitab tafsir dari yang klasik sampai modern menggunakan dua pendekatan. Pertama, pendekatan eksoterik (eksoterik), yakni tafsir yang lebih menitikberatkan pada sisi lahir teks-teks Alquran. Kedua, pendekatan esoterik, yakni tafsir yang lebih menitikberatkan pada sisi isyarat atau pesan batin yang secara implisit terkandung di balik lahir teks-teks Alquran. Sejauh ini, perhatian para ulama terhadap pendekatan pertama lebih dominan daripada pendekatan kedua. Di antara indikasinya adalah keberhasilan mereka dalam merumuskan beragam metode (manhaj) penafsiran eksoterik. Indikasi lainnya yang dapat diajukan adalah produk-produk penafsiran eksoterik lebih banyak daripada produk penafsiran esoterik. Sejauh ini, belum

\footnotetext{
yang diulang-ulang itu disebut nazir/naza'ir, sedangkan maknanya yang berbeda-beda disebut wajh/wujuh. Dengan demikian, naza'ir berkenaan dengan kata, sedangkan wuju>b berkenaan dengan makna. Definisi lain dikemukakan Al-Zarkashi. Menurutnya, wujuh adalah kata yang mushtarak (polisemi), yakni satu kata yang memiliki makna lebih dari satu, seperti kata "al-ummab", sedangkan naz\} $a>$ 'ir adalah kata kata yang bermiripan. Lihat lebih lanjut pada Fahd ibn Abd AlRahman ibn Sulaiman Al-Rumi, Ushul al-Tafsir wa Manabijub, (Riyadh, 1413 H.), 127-129 dan Muhammad Ibn Alawi Al-Maliki Al-Hasani Zubdah al-Itqan fì Ulum al-Qur'an, Jeddah: Dar AlShuruq, 1983), h. 124-127.

7 Abdul Mustaqim menyebut adanya keragaman penafsiran ini sebagai Madhabib al-Tafsir. lihat Abdul Mustaqim, Madhabibut Tafsir: Peta Metodologi Penafsiran al-Quran, Periode Klasik. bingga Kontemporer (Yogyakarta: Nun Pustaka, 2003).

8 Untuk faktor-faktor yang melatarbelakangi para mufasir berbeda pendapat dalam menafsirkan Al-Qur'an dapat dilihat pada Ahmad Ibn Taimiyah, Muqaddimah fi Ushul al-Tafsir, (Kairo: Maktabah Al-Turath Al-Islami, t.t.),h. 34-36.

${ }^{9}$ Ahmad Ibn Taimiyah, Muqaddimah fi Ushul Aal-Tafsir, h. 32.
} 
ditemukan penjelasan memadai untuk menggambarkan fenomena di atas. ${ }^{10}$

\section{Mengenal Tafsir Esoterik}

Dalam kamus Bahasa Indonesia, tafsir berarti penjelasan terhadap satu kalimat (eksplanasi dan klarifikasi), yang juga mengandung pengertian penyingkapan, penunjukkan dan keterangan dari maksud dari satu ucapan atau kalimat.11 Para pakar 'Ulumul al-Qur'an seperti Imam As-Suyuthi dalam al-Itqan mengatakan kata tafsir terbentuk dari pola "Tafil" dari kata al-Fasr yang berarti penjelasan (al-Bayan) dan pengungkapan (al-Kasyif) atau al-Tafsirah yang berarti urine sebagai indikator penyakit. ${ }^{12}$

Dalam bahasa Inggris menafsir diistilahkan dengan kata "Exegesis" yang memiliki arti membawa keluar atau mengeluarkan. Apabila dikenakan pada tulisan-tulisan, maka kata tersebut berarti "membaca atau menggali" arti tulisan tersebut. Jadi pada waktu kita membaca sebuah tulisan atau mendengar suatu pernyataan yang kita coba fahami dan tafsirkan, maka kita sebenarnya sedang melakukan penafsiran. ${ }^{13}$

Lafadz Tafsir dan diartikan dengan penjelasan terulang, dan didalam Alquran, hanya satu kali yaitu dalam QS. Al-Furqan (25) ayat 33:

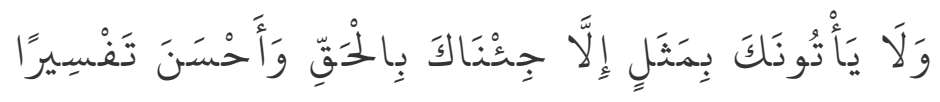

Tidaklah orang-orang kafir itu datang kepadamu (membawa) sesuatu yang ganjil, melainkan kami datangkan kepadamu suatu yang benar dan yang paling baik penjelasannya (Qs. al-Furqan [25]:33)

10 Nicholas Heer, "Tafsir Esoterik Al-Qur'an Abu Hamid Al-Ghazali", dalam Seyyed Hossen Nasr, et. al., (Ed.), Warisan Sufi, terj. Gafna Raizha Wahyudi dari The Heritageof Sufism,h. 292.

11 Pusat Studi Bahasa, Kamus Besar Bahasa Indonesia (Jakarta: Balai Pustaka, 2002), h.1119.

${ }^{12}$ Jalaluddin As-Suyuti (selanjutnya disebut As-Suyuti), Al-Itqan fi Ulum al-Qur'an (kairo: Maktabah Dar at-turats, 1983), 167.

${ }^{13}$ John Hayes dan Carl Holladay, Pedoman Penafsiran al-Kitab (Jakarta: BPK Gunung Mulia, 1993), h. 1. 
Adapun pengertian tafsir menurut istilah adalah sebagai berikut: Pertama, Menjelaskan kalam Allah, dengan kata lain berfungsi sebagai penjelas bagi lafazh-lafazh Alquran beserta maksudnya. Kedua, Mengungkapkan makna Alquran dan menjelaskan maksudnya. ${ }^{14}$

Sedangkan kata 'esoterik' berasal dari bahasa Inggris yang artinya rahasia atau tersembunyi. Dalam bahasa Arab kata tersebut memiliki kesamaan makna dengan kata 'bathin', lawan kata 'zhahir'. Secara etimologi, bathin berarti "sesuatu yang dikandung oleh sesuatu" (Mâ Yujad Dakhil al-Sya'i). Bila dikaitkan dengan teks, bathin artinya makna yang tersembunyi (al-Khafi), rahasia (al-Sirriyy), dalam (al-Amiq), tertutup (al-Mastur), yang tersembunyi bagi selain ahlinya (al Maktum an ghair ahlih). ${ }^{15}$ Dalam kebiasaan orang Arab, kata bathin juga digunakan dalam konteks kinayah (antonomasia). ${ }^{16}$

Tafsir esoterik yang dikehendaki dalam penelitian ini adalah segala bentuk penafsiran yang berupaya menggali makna batin Alquran, Beberapa penelitian telah memperkuat hal itu. Umpamanya, Henry Corbin (pengkaji Islam berkebangsaan Islam yang pernah menulis tentang sufisme Ibn Arabi), Habil, dan Hudgson menggunakan kata "esoteric" dalam konteks tersembunyi, esoterik, dan internal yang berbeda dengan Tafsir yang bersifat literal, eksternal, dan lahir. ${ }^{17}$

\section{Sejarah dan Perkembangan Tafsir Esoterik}

Untuk dapat mengetahui mengenai sejarah dan perkembangan tafsir esoterik, ada beberapa literatur yang dapat dirujuk. Di

\footnotetext{
${ }^{14}$ Muhammad bin Sulaiman al-Khafiji, at-Taisir fi Qawaid Ilm Tafsir (Beirut: Dar al-Qalam, 1990), h. 124.

${ }^{15}$ Adil al-Awa, "Bathin-Zhahir", dalam Maan Ziyadah, (Ed.), Al-Maushuah Al-Falsafiyyah AlArabiyyah (Saudi Arabia: Mahad Al-Inma' Al-Arabi, 1986), cet. ke-1, h. 175.

16 Adil al-Awa, Bathin-Zhabir, h.178.

${ }^{17}$ Henry Corbin, Creative Imagination in the Sufism of Ibn Arabi (Princeton University,1969), h. 78; Abdurrahman Habil, "Traditional Esoteric Commentaries on the Qur'an", dalam Seyyed Hossen Nasr (Ed.), Islamic Spirituality Foundations (New York: Crossroad, 1991), h. 25; Lihat Marshall G.S. Hudgson, The Venture of Islam (Chicago and London: The University of Chicago Press, 1974), v. II, h. 225.
} 
antaranya adalah yang ditulis Muhammad Husain AlDzahabi, ${ }^{18}$ Abdul Tawwab Abdul Hadi, ${ }^{19}$ dan Abdurrahman Habil. Dari tiga literatur di atas, yang ditulis oleh tokoh terakhir lebih sistematis, karenanya kerangka pembagiannya akan digunakan oleh penelitian ini. Al-Dzahabi dan Hadi memang sama-sama menyinggung perkembangan tafsir di kalangan sufi, filosof, dan teolog - terutama dari Syi'ah, tetapi tidak ditempatkan dalam kerangka kronologisnya, tidak sebagaimana yang dilakukan Habil. Habil membagi sejarah dan perkembangan tafsir esoterik kepada lima periode berikut ini: (1) periode paling awal, ketika seluruh akar tradisi dapat ditemukan; (2) periode yang bertepatan dengan waktu ketika tafsir-tafsir sufi awal ditulis; (3) periode Syi'ah Dua-BelasImam, ketika pusat tafsir esoterik Alquran berpindah ke Persia; (4) periode tafsir-tafsir sufi klasik besar; dan (5) periode masa kini. ${ }^{20}$

Dasar pembabakan yang dilakukan Habil adalah abad dan perkembangan tafsir mulai dari masa Nabi dan sahabat tatkala belum ada kodifikasi tafsir sampai pada perkembangan ketika tafsir sudah terkotak-kotak berdasarkan aliran-aliran tertentu. Periode pertama, misalnya, diawali pada abad I - III H. Pada saat itu, tafsir belum dikodifikasikan, bahkan sebagai sebuah ilmu sendiri pun tafsir $r$ belum muncul. Periode kedua dimulai Abad III - VII H. Pada periode ini tafsir sebagai sebuah ilmu sudah muncul. Kodifikasi sudah ada, dan pada perkembangan selanjutnya kodifikasi tafsir sudah terpisah dari hadits. Pada periode ini pula, tafsir sudah terkotak-kotak pada aliran-aliran yang berkembang. ${ }^{21}$ Begitu pula pada periode ketiga

18 Muhammad Husein Al-Dzahabi, al-Tafsir wa al-Mufassirun, (Mesir: Dar Al-Maktub AlHaditsah, 1976), jilid 2.

${ }^{19}$ Abdul Tawwab 'Abdul Hadi, Lambang-Lambang Sufì di dalam Al-Qur'an, terj. Afif Muhammad dari Al-Ramiiyyah Al-Shufiyyah fî Al-Qur'an Al-Karim, (Bandung: Pustaka, 1986).

20 Abdurrahman Habil, "Traditional Esoterik Commentaries on the Qur'an", dalam Seyyed Hossen Nasr (Ed.), Islamic Spirituality Foundations, (New York: Crossroad, 1991), h. 25; Abdurrahman Habil, "Tafsi $>r$-Tafsi $>r$ Esoterik Tradisional Al-Qur'an", dalam Seyyed Hossein Nasr (Ed.), Ensiklopedi Temastis Spiritualitas Islam, terj. Rahmani Astuti, (Bandung: Mizan, 2002), cet. Ke-1, h. 32

21 Rosihon Anwar, "Tafsir Esoterik Menurut Pandangan Al-Thabathaba'i” Disertasi Pasca Sarjana UIN Syarif Hidayatullah Jakarta (Jakarta: 2004). 
(Abad VIII - X H), keempat (Abad XI - XIII H), dan kelima (Abad XIV H. Sampai Sekarang).

\section{Model-Model Tafsir Esoterik}

Di dalam literatur Ulumul al-Qur'an sendiri dikenal beberapa istilah teknis yang sekaligus menjelaskan model tafsir esoterik. Istilah-istilah itu adalah al-Tafsir al-Bathini'22 atau Bathiniyyah,,23 Tafsir Isyarî24 yang oleh Manna Al-Qaththan diidentikkan dengan al-Tafsir al-Faidhi,25 al-Tafsir al-Ramzi,26 al-Tafsir bi Bâthin al-Qur'an,27 'al-manhaj al-ramzi', al-tafsir al-shufi, dan al-manhaj altamtsili, ${ }^{28}$ dan al-tafsir alirsyadi. 29

Dengan demikian, ada delapan istilah berbeda telah digunakan para ulama berkenaan dengan model tafsir esoterik, yakni al-Tafsir alBathini' atau Bathiniyyah, Tafsir Isyari, al-Tafsir al-Faidhi, al-Tafsir alShufi, al-Tafsir/al-Manhaj al-Ramzi, al-Tafsir bi Bathin al-Qur'an, dan alManhaj al-Tamtsili. Delapan istilah itu, karena beberapa di antaranya merupakan kata lain dan sebagian lainnya merupakan sub-varian sebagaimana akan dijelaskan, memperlihatkan empat model Tafsir

\footnotetext{
22 Ungkapan seperti ini, di antaranya, dipakai oleh Muhammad Ali Al-Shabuni, Al-Tibyan fî Ulum al-Qur'an, (Beirut: Alam Al-Kutub, t.t.), h. 174.

23 Ungkapan seperti ini, di antaranya, dipakai oleh Muhammad Ali Al-Shabuni, Al-Tibyan fî Ulum al-Qur'an, h. 174.

24 Shubhi Shalih, Mabahits fí Ulum Al-Qur'an, (Beirut: Dar Al-'Ilm li Al-Malaya, 1988), Cet. ke-17, hlm. 296; Muhammad Abd Al-Azhim Al-Zarqani, Manahil Al-Irfan fî̀ 'Ulum al-Qur'an, (Beirut: Dar Al-Fikr, t.t.), Jilid 2, h. 78.

25 Mannaa Al-Qaththan, Mabahits fî Ulum al-Qur'an, (Mesir: Mansyurat Al-Ashr Al-Hadits, 1973), h. 357.

${ }^{26}$ Istilah ini diperkenalkan oleh, di antaranya, Al-Dzahabi (1333-1365 H/1915-1945M) dan Abu Muhammad Al-Syirazi (w. 666 H/1258M), penulis kitab tafsir isyari berjudul Ara'is al-Bayan fí Haqa'iq al-Qur'an. Lihat Muhammad Husain Al-Dzahabi, al-Tafsir wa Al-Mufassirun, (Mesir: Dar Al-Maktub Al-Haditsah, 1976), Jilid 2, h. 141; 'Abdul Tawwab Abdul Hadi, Lambang-Lambang Sufí di dalam Al-Qur'an, terj. Afif Muhammad dari Al-Ramziyyah Al-Shu>fiyyah fì al-Qur'an Al-Karim, (Bandung: Pustaka, 1986), h. 1.

27 Muhammad Hadi Marifah, al-Tambid fî̀ Ulum al-Qur'an, (Qum: Mu'assasah Al-Nasyr AlIslami>, 1416/1995), Jilid 3, cet. ke-3, h. 30.

${ }^{28}$ Ketiga istilah ini diperkenalkan oleh Ahmad Khalil. Lihat Ahmad Khalil, Dirasat fî alQur'an, (Mesir: Dar Al-Maarif, t.t.), h. 117, 129.

${ }^{29}$ Istilah ini diperkenalkan oleh Al-Alusi (w. $\left.1270 \mathrm{H} / 1854 \mathrm{M}\right)$ dan Al-Naisaburi (321—405 H./933-1014 M.), dalam Al-Ragha'ib al-Furqan. h. 128
} 
esoterik, yaitu (1) al-Tafsir al-Bathini, (2) al-Tafsir al-Shufi, (3) al-Tafsir al-Isyari, dan (4) al-Tafsir al-ramzi. Berikut ini adalah uraiannya.

Model tafsir esoterik yang pertama adalah al-Tafsir al-Bathini. Sebagaimana dijelaskan Al-Shabuni, istilah ini berarti penafsiran yang dipraktekkan kelompok Bathiniyyah yang "memalingkan/merubah" (yuharrifûn) makna-makna Alquran serta menolak makna eksoterik Alquran. ${ }^{30}$ Dengan demikian, al-Tafsir alBathini baginya identik dengan Bathiniyyah. Sinonimnya adalah alTafsir al-Bathini yang tidak saja muncul didalam literatur-literatur Ulumul Qur'an, tetapi juga dalam literatur Ilmu Kalam. ${ }^{31}$ Siapa yang dimaksud dengan kelompok Bâthiniyyah sendiri, al-Shabuni tidak memberi penjelasan lebih lanjut. Namun, beberapa literaturlain menyebutkan bahwa kelompok yang dimaksud adalah Syi'ah Isma'iliyyah. ${ }^{32}$ Sementara itu, Ibn Taimiyah (w. 728 H/1328 M) menyebutkan bahwa kelompok yang dimaksud adalah Qaramithah ${ }^{33}$

30 Shabuni, al-Tibyan, .h 174-175.

${ }^{31} \mathrm{Abu}$ Al-Farj, Talbîs Iblîs, (Bairut: Dar Al-Kutub Al-Arabi, 1985), Jilid I, Cet. ke-1, h. 132, 133; Ibn Taimiyyah, Minhâj Al-Sunnah Al-Nabawiyyah, (Mu'assasah Qurthubah: 1406/1985), jilid 4, Cet. ke-1, h. 519; Abu Manshur Al-Baghdadi, al-Farq bain al-Firaq wa Bayan al-Firqah al-Najiyyah, (Bairut: Dar al-Afak al-Jadidah, 1977), Jilid 1, Cet. ke-2, hlm. 265,268; Muhammad ibn 'Abd AlKarim Al-Syahrastani, Al-Milal wa Al-Nibal, (Kairo: Maktabah Al-Halabi, 1387/1966), h. 192; Lihat, umpamanya, Philip K. Hitti, History of the Arabs, (London: Mac Millan, 1970), hlm. 443. Lihat pula Moojan Momen, An Introduction to Shi'i Islam, (New Haven and London: Yale University Press, 1985), h. 55

32 Dzahabi, al-Tafsir, Jilid 2, h. 235.

33 Nama ini dinisbatkan kepada pemimpinnya, Hamdan Qarmuth ibn Asy'ats. Penyebarannya meliputi daerah Arabia, Siria, Iraq, dan sebelah utara sungai Amu Darya. Mereka berhasil mendirikan "negara Qarâmithah" di Bahrain pada tahun 283-370 H. Kelompok ini pernah menimbulkan huru-hara dan kekacauan. Pada tahun 319 H. mereka menyerang Mekah, merampok dan membunuh para jemaaah haji, merusak sumur zam-zam, menjebol pintu Ka 'bah, lalu menyungkil Hajar Aswad dan membawanya pulang ke Bahrain. Baru 20 tahun kemudian, tahun 339 H., benda itu dikembalikan ke Mekah. Ajaran yang paling menonjol dari aliran ini adalah anarkisme, suatu ajaran yang dibangun di atas landasan nihilisme, yang tidak mengaku norma keagamaan dan menganggap segala sesuatu milik bersama. Mereka meninggalkan semua ibadah yang diajarkan agama dan tidak melarang perbuatan yang diharamkan agama atas harta dan wanita. LihatAbdullah Annan, Gerakan-Gerakan yang Mengguncang Islam, terj. Shaleh Mahfuzh dari Al-Tsaurah ala al-Islam, (Surabaya: Pustaka Progressif, 1993), h. 121-122. 
dan Nashiriyyah, ${ }^{34}$ dua sub-aliran Syi'ah Isma'iliyyah, dan para ekstrimis dari kalangan filosof, mutakallim, dan sufi. ${ }^{35}$

Dalam literatur Ilmu Kalam, kata "bathiniyyah" mempunyai konotasi sub-aliran Syi'ah Isma'iliyyah yang mempunyai pandangan bahwa Alquran mempunyai dimensi makna lahir dan batin. ${ }^{36}$ Pengkonotasian Bathiniyah dengan Syi'ah Isma'iliyyah disebabkan anggapan banyak pengamat tafsir bahwa sub-aliran ini mempunyai keyakinan bahwa makna batinlah yang dikehendaki Alquran, bukan lahirnya. ${ }^{37}$

Model tafsir esoterik yang kedua adalah al-tafsir al-shufî (tafsir sufistik), atau al-tafsir al-irsyadi. Menurut Al-Dzahabi, model ini terbagi kepada dua macam, yakni al-Tafsir al-Shufi al-Nazhari (Tafsir sufistik teoritis) dan Tafsir Isyari atau al-Tafsir al-Faidhi. Yang dimaksud dengan macam pertama adalah tafsir yang ditulis berdasarkan sudut pandang pembahasan, pengamatan, dan pengkajian sufistik. Adapun maksud yang kedua adalah penakwilan atas ayat Alquran yang menghasilkan penafsiran berbeda dengan dimensi lahirnya, karena tuntutan isyarat-isyarat yang hanya nampak bagi pemilik suluk dan memungkinkan mengkompromikannya dengan dimensi lahir yang dimaksud. Perbedaan antara keduanya adalah bahwa yang pertama dibangun atas dasar argumentasi teoritis, sedangkan yang kedua dibangun atas dasar praktek tasawuf, seperti riyadhah ${ }^{38}$ dan sebagainya. Ungkapan

\footnotetext{
${ }^{34}$ Nama ini dinisbatkan kepada Nashir ibn Khasr. Ia, menurut satu sumber, seorang penyair dan menyesatkan banyak orang.

35 Ibn Taimiyah, Kutub wa Rasa'il wa Fatawa Ibn Taimiyah fî Al-Tafsir, (ttp.: Maktabah Ibn Taimiyah, t.t.), jilid 13, h. 236.

${ }^{36}$ Hitti, History, hlm. 443. Momen, An Introduction, h. 55.

${ }^{37}$ Lihat umpamanya Dzahabi, Al-Tafsir, jilid 2, hlm. 9; Zarqânî, Manabil, Jilid 2, h. 74.

38 Riyadhah, yang sering juga disebut sebagai latihan-latihan mistik, yang dimaksudkan di sini adalah latihan kejiwaan dengan melalui upaya membiasakan diri agar tidak melakukan hal-hal yang mengotori jiwanya. Riyâdhah dapat pula berarti proses internalisasi kejiwaan dengan sifat-sifat terpuji dan melatih membiasakan meninggalkan sifat-sifat jelek. Para sufi memasukkan riyadhah sebagai pelatihan kejiwaan dalam upaya meninggalkan sifat-sifat jelek. Masuk di dalamnya adalah pendidikan akhlak dan pengobatan penyakit-penyakit hati. Para sufi memandang bahwa untuk menghilangkan penyakit-penyakit itu, perlu dilakukan riyadhah. (Abu Hamid Al-Ghazali, Ihya Ulum Al-Din, (Indonesia: Dar Al-Ihya' Al-Kutub Al- 'Arabiyyah, t.t.), Jilid 3, h. 395.
} 
yang terakhir sekaligus membedakan jenis tafsir ini dengan jenis tafsir yang dilakukan kelompok Bâthiniyah.

Model tafsir esoterik yang ketiga adalah tafsir isyari. Pengelompokannya sebagai model tafsir esoterik tersendiri merupakan versi lain tentang hakekatnya. Sebagaimana telah diutarakan di atas, tafsir ini, menurut Al-Dzahabi, merupakan subvarian al-Tafsir al-Shufi. Namun, versi lain yang dikemukan Ahmad Khalil, tafsir ini merupakan varian tersendiri dan berbeda secara signifikan dengan al-tafsir al-shufi. Baginya, apa yang oleh para ulama dikatakan dengan tafsir isyari sesungguhnya adalah tafsir ramzig shufi. Adapun tafsir isyari sendiri justru merujuk kepada tafsir yang ditulis para teolog dan fuqaha. ${ }^{39}$

Menurut Nashr Abu Zaid (1. 1943 M), terdapat perbedaan epistemologi antara Tafsir esoterik (di kalangan teolog dan filosof) dengan Tafsir isyari. Bila yang pertama, maksudnya Tafsir esoterik di kalangan filosof dan teolog rasional seperti Mu`tazilah, menggunakan perangkat takwil yang dihasilkan akal, sedangkan yang kedua menggunakan takwil yang dihasilkan rasa (dzauq). ${ }^{40}$

Dari perbincangan di atas dapat ditarik benang merah bahwa baik tafsir isyari, atau tafsir al-ramzi (simbolik), atau bathiniyyah samasama berusaha mengungkap makna implicit (batin atau esoterik) yang berada di balik makna eksplisit/lahir/eksoterik ayat Alquran. Sesungguhnya apa yang dilakukan oleh mufasir sufi dengan tafsir isyari-nya secara teknis tidak berbeda dengan apa yang dilakukan oleh mufasir teolog dan filosof dengan Tafsir ramzinya, yakni samasama menggali -sekali lagi- makna yang tersimpan di balik lahir ayat. Perbedaannya adalah menyangkut hasil pencariannya atau produk penafsirannya. Namun, dalam beberapa literatur Ulumul al Qur'an, tafsir isyari khusus diberikan berkenaan dengan penggalian makna esoterik Alquran di kalangan mufasir sufi. Adapun untuk praktek

\footnotetext{
${ }^{39}$ Khalil, Dirasat, h. 127-128.

${ }^{40}$ Lihat Nashr Hamid Abu Zaid, Mafbum Al-Nash, (Bairut: Al-Markaz Al-Tsaqafî Al- Arabi, 1998), h. 5
} 
serupa yang dilakukan para mufasir teolog dan filosof, Literatur Ulumul al-Qur'an menyebutnya dengan Tafsir bathini.

\section{Dinamika Takwil}

Secara Lughatan (Bahasa) Kata at-takwil ( التأويل) adalah sebuah kosakata Bahasa Arab yang terbentuk dari kata dasar (آل (âla) yauluaulan yang berarti kembali kepada asal ${ }^{41}$ (الرجوع). Kata tersebut jika diuraikan, maka akan terbentuk awwala, yuawwalu ta'wilan (أول تأويلا 42. Ar-Raghib al-Asfahani menyebutkan beberapa arti antara lain kembali ke asal (الرجوع الى الاصل ), mengembalikan sesuatu pada tujuan yang dikehendaki baik berupa pengetahuan maupun perbuatan. ${ }^{43}$

Mentakwil kalam berarti menjelaskan dan mengembalikan kepada maksud yang diharapkan.44 Ibnu Manzhur mendefinisikan takwil secara etimologi berarti ruju' (kembali) seperti bunyi hadis Man Shama ad-Dahr Fala Shama Wala Ala (barang siapa yang puasa selamanya maka sebenarnya dia tidak puasa dan tidak kembali kepada kebaikan). ${ }^{45}$ Abu Ubaidah Ma'mar Ibn al-Mutsanna dan atThabari mengartikan takwi>l adalah Tafsir, marja' dan al-mashir. ${ }^{46}$

Ath-Thabari, imam para mufassir menamai kitabnya dengan Jami' al-Bayan 'an Takwil Ay al-Qur'an dalam setiap penjelasannya terhadap ayat Alquran sering memulainya dengan "al-Qaul fi Takwil Qaulihi Ta'ala Kadza...". Lebih lanjut dalam muqaddimah Tafsirnya, beliau menjelaskan bahwa takwil ayat Alquran terbagi ke dalam tiga bagian, yaitu: Pertama, takwil yang tidak bisa diketahui oleh siapa

${ }^{41}$ Louis Ma'luf, al-Munjid, (Beirut: Da>r al-Masyriq, 1975), Cet. XXVI, h. 21. Lihat juga Hans Wehr, a Dictionary of Modern Written Arabic, London: Wiesbaden 1971, h. 34. Dia mengartikan آل آلإيالة dengan return dan revert. Adapun katan dengan regency dan province. Sedangkan JG Hava mengartikan الإيالة dengan government. Lihat JG. Hava, al-Fara'id alDurriyyah, Beirut: Catholic Press, 1964, h. 17

42 Warson Munawir, Kamus al-Munamwir, (Yogyakarta: Unit Pengembangan Buku-Buku Ilmiah Keagamaan Pondok Pesantren al-Munawwir, 1984), h. 52.

${ }^{43}$ Raghib al-Asfahani, Mu'jam Mufradat al-fadzdi al-Qur'an, (Beirut: Da>r al-Fikri, tt), h 27.

${ }^{44}$ Ibrahim Madkour, al-Mu'jam al-Wasith, (Kairo: 1960), Jilid I, h. 33, t.d.

${ }^{45}$ Ibnu Manzhur, Lisan al-'Arab, (Beirut: Dar al-Fikr, 1990), Jilid 11, h.32

${ }^{46}$ Muhammad Adib Shalih, Tafsir an-Nushush fi al-Figh al-Islami, (Kairo: Mansyurat al-Kutub al-Islami, t.t.), Jilid 1, h. 356 
pun kecuali Allah Swt. Kedua, takwil yang hanya diketahui oleh Nabi Muhammad Saw dengan izin ilmu Allah seperti takwil ayat-ayat hukum dan faraidl dan yang lainnya yang tidak mungkin diketahui kecuali dengan penjelasan dari Rasulullah. Untuk bagian ini, seseorang tidak dibolehkan melakukan takwil kecuali dengan dalil dari Nabi. Ketiga, takwil yang diketahui oleh mereka yang memiliki otoritas dan ilmu pengetahuan tentang ayat Alquran. ${ }^{47}$

Sedangkan menurut ulama mutaakhirin baik dari kalangan fuqaha, mutakallimin, ahli hadis dan ahli sufi berpendapat bahwa takwil adalah memalingkan lafazh dari makna yang zhahir kepada makna yang lebih kuat kemungkinannya disertai dengan dalil-dalil.48 Dalam hal ini, tugas takwil terbagi menjadi dua yaitu menjelaskan kemungkinan makna lafazh dan menjelaskan dalil yang bisa memalingkan dari maknanya yang asli. Ad-Dzahabi setelah memaparkan pengertian takwil menurut para ulama, lebih memilih kepada pengertian bahwa takwil berkaitan dengan aspek dirayah yang berpegang kepada perangkat ijtihad dengan mengetahui karakteristik bahasa Arab. 49

Dari berbagai bahasan tentang definisi takwil, kita dapat menyimpulkan dua makna takwil yaitu: Pertama, takwil adalah mengalihkan makna dari yang meragukan atau membingungkan pada makna yang meyakinkan dan menentramkan. Dalam pengertian ini, takwil hanya berhubungan dengan ayat-ayat mutasyabihat. Kedua, takwil adalah selain makna lahiriah juga termasuk makna bathiniyah. takwil dalam arti ini berhubungan dengan semua ayat Alquran. Ar-Raghib al-Isfahani memberikan tanggapan bahwa tafsir lebih umum dibandingkan takwil dan biasanya kata tafsir lebih banyak digunakan dalam lafaz dan mufradatnya sedangkan takwil lebih dititikberatkan kepada makna

Ibnu Jarir Ath-Thabari, Muqaddimah at-Tafsir, (Beirut: Dar al-Fikr, 1988), h. 92, Lih, juga M. Adib Shalih, Tafsir an-Nushush. h. 363

48 Adz-Dzahabi., al-Tafsir wa al-Mufassirun., h. 18

${ }^{49}$ Adz-Dzahabi., al-Tafsir wa al-Mufassirun. h. 18 
dan kalimat serta sering dikenakan pada kitab-kitab suci, hal tersebut berbeda dengan tafsir yang digunakan pada selain kitab suci. ${ }^{50}$

Perbedaan ini tidak terlepas dari ruang lingkup tafsir dan takwil yang bekerja pada dua sisi makna Alquran, yakni makna zahir dan makna bathin. Dikotomi zhahir dan bathin sebagai dua sisi makna Alquran dipertemukan dengan pembedaan tafsir dan takwi>l sebagai dua metode pendekatan. takwil difahami sebagai kaedahkaedah penafsiran berdasarkan akal terhadap ayat-ayat allegoris yang bertujuan untuk sebanyak mungkin menyingkap makna yang terkandung di dalam suatu teks serta memilih yang tepat. Sedangkan tafsir difahami sebagai penjelasan yang hanya bersumber dari khabar benar yang diriwayatkan secara mutawatir oleh para perawi yang adil dan dhabith hingga kepada para Sahabat dan Nabi Muhammad Saw.

Terkadang ada yang menganggap bahwa tafsir dan takwil merupakan sinonim, sebab metodenya dianggap persis/sama. Akan tetapi, makna yang dicapai oleh tafsir tidak dapat diperluas dengan takwil khususnya dalam penafsiran hukum. Contoh klasik tentang sifat ilmiah takwil dan hubungan integralnya dengan takwil ditunjukkan oleh Al-Jurjani dalam kitab at-Ta'rifatnya, yakni: Ketika Allah Swt berfirman bahwa : "Dia melahirkan (sesuatu) yang hidup dari yang mati (yukhriju al-hayy min al-mayyit) dan untuk sekedar memberikan contoh, kita menafsirkan dengan pengertian bahwa Dia menjadikan burung dari telur, maka ini adalah tafsir. Akan tetapi ketika kita mengartikan kalimat yang sama dengan pengertian bahwa Dia menjadikan orang yang beriman dari kafir atau Dia melahirkan orang alim dari yang jahil maka inilah yang disebut dengan takwil .51

Apabila kita membahas tentang takwil maka kita tidak dapat terlepas juga dari pembahasan Mutasyabihat, karena salah satu area pembahasan takwil adalah ayat-ayat mutasyabihat atau ayat-ayat

50 Az-Zarkasyi, al-Burban, h.152.

51 Al-Jurjani, Kitab at-Ta'rifat (Beirut: Dar at-Turats,t.t),h.72. 
yang ambiguous. Mutasyabihat diambil dari kata Syabaha yaitu apabila salah satu dari dua hal serupa dengan hal yang lain, ${ }^{52}$ saling menyerupai sehingga sulit untuk menentukan pilihan. Dalam bahasa Indonesia, kata Syubhah memiliki arti keragu-raguan/ kebimbangan atau kekurangjelasan terhadap sesuatu, juga mengandung suatu keadaan yang kurang atau tidak jelas status hukumnya, yakni suatu keadaan dimana satu dari dua hal tidak dapat dibedakan karena adanya kemiripan antara keduanya. Dari sini kita dapat menarik benang merah bahwa mutasyabih adalah redaksi yang memunculkan makna "samar" atau "tidak jelas".

Dengan tidak adanya kata sepakat tentang batasan arti dari pengertian mutasyabih, maka cukup sulit untuk merumuskan kriteria tentang mana ayat-ayat yang termasuk muhkamat dan mana ayat-ayat yang mutasyabihat. Sebagaimana disinggung sebelumnya, hal ini mungkin dikarenakan suatu ayat disebut muhkam oleh sebagian ulama, namun dianggap mutasyabih oleh Ulama yang lain. Sebagai contoh, ayat-ayat yang berkenaan dengan syurga dan neraka oleh sebagian Ulama dianggap muhkam, akan tetapi dianggap mutasyabih oleh Ulama yang lain. Golongan Bathiniyyun misalnya, menganggap ayat-ayat tersebut termasuk ke dalam kelompok ayat mutasyabihat, karena menurut mereka gambaran tentang syurga dan neraka difahami sebagai metafora-metafora yang tidak langsung menuju kepada hakikatnya. ${ }^{53}$

\section{Takwil Nasr Hamid Abu Zaid sebagai Tafsir Esoterik dalam merespon Problem Tafsir Modern}

Metode penafsiran ala hermeneutik yang dikembangkan oleh pemikir kontemporer yang salah satunya adalah Nasr Hamid Abu Zaid ini dipandang lebih aspiratif bagi pluralitas ketimbang penafsiran yang berkembang selama ini dalam tradisi Islam. Sebab,

${ }^{52}$ Louis Ma'luf, al-Munjid: Fi al-lughah wa al-A'lam (Beirut: Dar al-Masyriq, 1983),h.372-373.

53 Nurcholish Majid, "Masalah Ta'wil Sebagai Metodologi Penafsiran al-Qur'an" dalam Budhy Munawar Rachman (ed)., Kontekstualisasi Doktrin Islam dalam Sejarah (Jakarta: Yayasan Paramadina, 1994), h.11-13. 
hermeneutik dipandang mempunyai tawaran alternatif bagi pemahaman dan penafsiran melalui pendekatan terhadap teks dengan berbagai asumsi, dari sini muncul dua mazhab, yaitu mazhab hermeneutika transcendental dan historis-psikologis. Yang pertama berpandangan bahwa untuk menemukan suatu kebenaran dalam teks tidak harus mengaitkan dengan pengarangnya karena sebuah kebenaran bisa berdiri otonom ketika tampil dalam teks. Yang kedua adalah berpandangan bahwa teks adalah eksposisi eksternal dan temporer saja dari pikiran pengarangnya, sementara kebenaran yang hendak disampaikan tidak mungkin terwadahi secara representatif dalam teks. ${ }^{54}$ Untuk memahami apa yang terkandung dalam teks itulah dibutuhkan sebuah proses penakwilan, namun terkadang proses penafsiran yang dilakukan oleh kalangan tertentu adalah memanfaatkan ayat sebagai estimasi pembenaran terhadap golongannya, akibatnya adalah pengakuan terhadap relativitas kebenaran penafsiran. Karena bagaimanapun juga, sebuah pemahaman dan penafsiran manusia terhadap teks Alquran bukanlah Alquran itu sendiri, ia hanyalah produk pemikiran dan penalaran yang tidak terlepas dari hal-hal yang mempengaruhinya. Jika sebuah pemahaman dan penafsiran dipandang sebagai absolute, tentu akibatnya adalah pengakuan adanya dua kebenaran mutlak; 55 hal yang sama sekali tidak dibenarkan dalam ajaran Islam.

Banyak dari diskusi yang lebih tenang justru memfokuskan pada dua argumen yang saling berkaitan yang merupakan inti dari karya Abu Zaid, pertama berkaitan dengan status historis Alquran; dan kedua, menekankan relasi akal ('aql) dengan agama (din). sebuah tinjauan terhadap diskusi ini mengungkapkan beberapa garis

${ }^{54}$ Gerald L. Bruns, Hermeneutics Ancient \& Modern (Yale University Press: 1992),h. 2-3.

${ }^{55} \mathrm{Abu}$ Zaid menyatakan tidak perlunya menganggap bahwa pemahaman Nabi Saw atas teks al-Qur'an sebagai petunjuk hakiki dari teks itu. Sebab, asumsi semacam itu akan berakibat pada kesyirikan, karena telah menyetarakan Yang Absolut dengan yang nisby, antara yang konstan dengan yang dinamis, antara maksud Tuhan yang absolute dengan pemahaman manusia yang relative. Pada akhirnya pandangan ini akan menyetarakan derajat Nabi yang tercipta dengan Tuhan yang Mencipta. Nasr Hamid Abu Zaid, Naqd al- Kbitab al- Dini> (Kairo: S \{ina> Li alNashr: 1992), h.125-126. 
kesalahan konseptual yang melintasi masyarakat Mesir dan praksis struktur politiknya.

Titik kunci dalam pemberangkatan dalam argumen Abu Zaid56 adalah ide yang memasuki sejarah, ketika Alquran diwahyukan pada Muhammad serta menjadi subjek dalam hukum atau aturan (qawanin) historis dan sosiologis. Dengan sifat tetapya (qodim) yang dikirim dari Ilahi yang murni, teks menjadi dimanusiawikan (humanized, muta'annas) dan mengejewantahkan berbagai elemen kultur, politik serta ideologi tertentu dari masyarakat Arab abad ke-7:

Alquran inti persoalan yang sangat penting dalam diskusi kita ini merupakan teks agama yang pasti dilihat dari sudut susunan kata literal, tetapi ketika teks menjadi subjek bagi akal manusia (al-'Aql alInsanu), maka ia menjadi sebuah "konsep" (mafhum) yang menghilangkan kepastiannya sehingga dia berubah dan maknanya pun berkembang... Penting sekali kita tegaskan di sini bahwa suasana teks suci yang orisinil adalah sesuatu yang metafisik yang tak dapat kita ketahui selain teks itu sendiri yang menyebutkannya dan yang selalu datang kepada kita melalui perubahan manusia secara historis. ${ }^{57}$

Dari peristiwa pengujarannya, teks Ilahi telah dibentuk dan secara kontinyu dibentuk ulang melalui operasi akal manusia. Karenanya jarak yang terjadi sekarang ini memisahkan teks dari Ilahi telah begitu banyak mengubah keseluruhan teks kecuali manusia. ${ }^{58}$ Dengan kata lain, pemisahannya dengan Ilahi tersebut terjadi di saat pewahyuan berlangsung yang menghasilkan pensekularisasian terhadap teks, yang selanjutnya menjadi sebuah buku seperti bukubuku yang lainnya: “Teks-teks keagamaan dalam analisis akhirnya,

\footnotetext{
56 Kebanyakan diskusi berikut ini didasarkan pada buku terbaru Abu Zaid yang diterbitkan dan digambarkan paling signifikan dalam laporan komite tetap tersebut: Naqd al-Khithab al-Dini (Kritik Wacana Agama) (Cairo: Dar al-Tsaqafah al-Jadidah, 1992). Karya ini meringkas tema yang paling inti dalam tulisan-tulisan Abu Zaid sebelumnya. Seluruh terjemahan Indonesia dalam tanda [] berasal dari penulis

57 Abu Zaid, Naqd al-Khithab al-Dini (Kritik Wacana Agama), 93

58 Abu Zaid, Naqd al-Khithab al-Dini (Kritik Wacana Agama), 96
} 
tidak lain adalah teks linguistik yang memiliki struktur budaya tertentu dan dihasilkan dalam berbagai aturan budaya tersebut" ${ }^{\prime 5}$

Realitas historis dimana Alquran ikut ambil bagian dalam cerita Abu Zaid merupakan, seperti yang digambarkan oleh seorang sosiolog realis, sebuah ruang persaingan ideologis dimana berbagai subjek kepentingan yang otonom (individu, kelompok, kelas) bersaing dengan pihak lainnya untuk tujuan politik dan ekonomi jangka pendek. Logika ruang semacam itu, misalnya menyatakan bahwa pemahaman yang benar terhadap Alquran harus dimulai dengan meletakkannya dalam konteks dominasi Quraisy dan karenanya sebagai bagian dari alat ideologis yang menopang kelas saudagar tertentu; hal ini (jika tidak keliru) muncul dari observasi sederhana bahwa, "(Prinsip) kedaulatan Tuhan hanya menghasilkan kedaulatan kaum Agamawan akhirnya, tidak lain kecuali manusia dengan berbagai bias dan kecenderungan ideologisnya". ${ }^{60}$ Memang seluruh argumen Abu Zaid, turunnya berbagai klaim kebenaran terhadap status ideologis, sebuah fungsi budaya dan kepentingan kelas, mendasari sebuah reinterpretasi agama yang menekankan motif dan ambisi pribadi yang tersembunyi. Sebagai contoh, perspektif semacam itu membawa kita kepada kesimpulan bahwa klaim-klaim kebenaran dan pengetahuan yang benar yang dibuat oleh para Ahli agama niscaya dalam realitasnya dibodohi oleh kelompok ini (dan sekarang kepentingan Negara dimana mereka menjalaninya) yang menjaga kekuasaan dan otoritasnya. ${ }^{61}$ Selain itu, argumen semacam itu membentuk ide Islam sebagai sebuah objek historis yang koheren yang tidak dapat dipertahankan melalui penegasan banyaknya variasi dalam praktek dan interpretasi Islam yang melampaui masa dan wilayah geografis. Sebagaimana pernyataan Abu Zaid, bahwa untuk menempatkan kesatuan semacam itu adalah berarti "mempertentangkan sejarah Islam yang

${ }^{59}$ Abu Zaid, Naqd al-Khithab al-Dini (Kritik Wacana Agama), 193

${ }^{60} \mathrm{Abu}$ Zaid, Naqd al-Khithab al-Dini (Kritik Wacana Agama), h.56. Bermacam tipe rezim politik seringkali memperkenalkan kedaulatan tertinggi dari Tuhan tanpa perlu mengakui otoritas keagamaan tertentu lebih dari semua urusan Negara.

${ }^{61}$ Abu Zaid, Naqd al-Khithab al-Dini (Kritik Wacana Agama), h.93. 
sebenarnya, yang telah menyaksikan sebuah pluralitas daalam berbagai kecenderungan, arus dan kubu yang muncul karena alasan sosial, ekonomi, politik." 62

Obyek, pelaku, bentuk-bentuk pengetahuan, dan tindakan merupakan sejarah pengosongan Tuhan dari agama (bisa diketahui secara manusiawi). Tidak mengherankan, dari perspektif ini kalangan liberal telahj mengakibatkan pengosongan, substitusi yang berpengaruh secara historis, melalui proses pencerahan yang progresif, melalui perjalanan yang bertahap dari mitos dan kesalahan, menuju kemajuan, sains, keadilan dan kebebasan; atau sebuah gerakan yang menghumanisasikan manusia dengan membuang berbagai tradisi yang membuatnya tunduk kepada teks dan para penafsirnya serta terus berkembang dengan dirinya sebagai pemilik takdir dirinya sendiri.63 Terutama, menurut Promotheus, sastra, bukan wahyu, membuka sesuatu kepada yang tak diketahui (unknown) dan transenden. Misalnya pertentangan antara teks dan agama:

Adalah jelas bahwa teks-teks agama tidak mengajukan problematika yang sama mengenai "tujuan" dengan teks-teks sastra; atau lebih dari itu, teks sastra mengajukannya pada tingkat epistemologis yang dibentuk melalui kondisi obyektif sosial, ekonomi, dan politik yang membatasi produksi teks-teks tersebut dan karenanya menetapkan bidang aplikasinya terhadap berbagai tanda dan makna orisinil dan fundamental. ${ }^{64}$

Artinya, kalau konsep transenden tidak selamanya berkaitan erat dengan tugas menjelaskan dan memahami teks keagamaan (hanya memerlukan analisis sosio historis), maka ia menemukan keberlangsungan aplikasinya dalam dunia bathin (inner world) yang tak terkatakan dari para penulis dan pembaca, sebuah ruang yang tak menentu yang digambarkan dalam konsep modern dengan tujuan sastra (literary intention). Jelasnya, langkah singkat dari semua

\footnotetext{
${ }^{62}$ Abu Zaid, Naqd al-Khithab al-Dini (Kritik Wacana Agama), h.96

63 Abu Zaid, Naqd al-Khithab al-Dini (Kritik Wacana Agama), h.110.

64 Abu Zaid, Naqd al-Khithab al-Dini (Kritik Wacana Agama), h.110.
} 
penelitian ini untuk mengklaim bahwa "sekularisme" (al-almaniyyat), pada dasarnya tidak lain kecuali interpretasi yang benar dan pemahaman saintifik terhadap agama." 65 Memang, segera sesudah belajar membedakan teks metafisik dari teks historis yang riil dan membawa yang metafisik sebagai sebuah obyek yang sesuai bagi pengetahuan, maka terbuka untuk menganalisis al-Qur'an seperti "system tanda" lainnya, baik berupa puisi, pola perilaku atau bahkan "trend fashion" sebagaimana ditegaskan Abu \Zaid secara provokatif.66

Tetapi, meski diduga terdapat struktur dialektis dalam metode penafsiran ini, kita menemukan bahwa metode tersebut tidak benarbenar menyimpang di luar wilayah horizon modernitas. Karena, sebagaimana dinyatakan Abu Zaid dalam pendahuluannya, "agama, ketika difahami secara benar, maka artinya bahwa agama tersebut sesuai dengan analisis dan interpretasi saintifik yang menolak kepalsuan dan mistik, namun memelihara apa saja yang mengembangkan kemajuan (taqaddum), keadilan ('adl), dan kebebasan (hurriyyat)".67 Bagian terdepan seluruh karyanya dan terpusat pada argumen tersebut, maka sasaran kalangan modernis selanjutnya adalah merancang kriteria interpretasi yang bisa diterima dan mendekatkan kepada seluruh horizon historis lainnya. Dengan demikian, ide bahwa hermeneutik membuka kepada makna yang tersimpan di masa lalu menjadi sedikit bermakna menurut penilaian negatif $\mathrm{Abu}$ Zaid terhadap penggunaan sejarah masa lalu. Dia menulis:

Kecenderungan wacana agama] untuk menghapuskan dimensi historis terlihat jelas dalam asumsi penyesuaian antara problem masa kini dan masa lalu, serta penerapan solusi masa lalu terhadap kondisi sekarang. Lagi pula, merujuk pada karya-karya ulama masa awal, dan pengartibusian status suci terhadap teks-teksnya, lebih jauh menghapuskan aspek historis ini dan membawanya pada kedalaman

${ }^{65}$ Abu Zaid, Naqd al-Khithab al-Dini (Kritik Wacana Agama), h.9.

${ }^{66}$ Nasr Hamid Abu Zaid, Mat al-Rajul wa Bada'at Mubakamatubu, Adab wa Naqd (Cairo, 1994),h. 67.

${ }^{67}$ Abu Zaid, Naqd al-Khithab al-Dini (Kritik Wacana Agama), h.9. 
aliensi manusia serta menutupi seluruh problem penerapan yang mengakar dalam realitas. ${ }^{6} 8$

Menurut Abu Zaid, masa lalu itu bergerak meninggalkan manusia jauh dari dirinya yang rill sebagai tindakan individu yang dituntun oleh akal dalam kata-kata pragmatis dan bertujuan jangka pendek, maka seruannya pada kaum Muslim untuk terus meneliti Alquran mungkin dipahami dengan baik sebagai sebuah respon taktis terhadap konteks sosial dari tulisannya sehingga menjadi aksesoris terhadap argumennya sendiri.

Tafsir esoterik menurut Nasr Hamid Abu Zaid yaitu penafsiran yang tidak hanya bertumpu pada sisi literal teks melainkan makna batin dari teks tersebut. Hal tersebut berbanding terbalik dengan tafsir eksoterik di mana penafsiran ini cenderung menafsirkan ayatayat Alquran bertumpu pada makna lahir teks (secara literal). Istilah eksoterisme pada mulanya lebih dikenal dalam dunia fiqh (hukum Islam). ${ }^{69}$ Dalam mazhab figh, kelompok ini merupakan kelompok yang sedikit sekali untuk tidak mengatakan menafikan sama sekali menggunakan $r a^{\prime} y u$-nya. Prinsip mereka dalam pengambilan hukum, tidak memperkenankan penggunaan akal. Kaidah mereka adalah: $\mathrm{La}$ ra'ya fi al-din (rasio tidak ada tempat dalam agama). Mazhab yang menggunakan kaidah semacam ini kemudian pada gilirannya disebut mazhab al-Zahiri ${ }^{70}$ Karena diprakarsai oleh Dawud al- Zahiri

68 Abu Zaid, Naqd al-Khithab al-Dini (Kritik Wacana Agama), h. 53.

${ }^{6}$ Seperti diketahui dalam Fiqh ta $>$ bi'i $>$ n, ada dua aliran besar dalam fiqh Islam, yaitu: abl alra'y dan abl al-hadits. Yang pertama mengedepankan rasio dalam pengambilan keputusan (baca: penetapan hukum). Sedangkan yang kedua berdasarkan fiqh (baca: pemahaman) pada $h$ $\}$ adi $>$ th meskipun lemah (dha'if) dan menolak rasio. Mazhab-mazhab fiqh terletak di antara kedua ekstrim itu. Kelompok pertama, yang mendasarkan pada ra'y (akal) dalam memahami nashsh (teks) Alquran maupun hadis disebut dengan istilah rasionalis, atau belakangan disebut dengan kelompok liberal. Sedangkan kelompok kedua, yang menganggap bahwa nashsh (teks) adalah segalanya dan merupakan satu-satunya sumber otoritas yang sah, disebut dengan istilah eksoterisme. Lihat Jalaluddin Rahmat, "Tinjauan Kritis atas Sejarah Fiqh; dari Fiqh al-Khulafa' al-Rashidin hingga mazhab Liberalisme" dalam http:www. geocities.com/anandito 2000/ensi/10-htm.

${ }^{70}$ Kelompok yang dikenal dengan "al-Zahiriyyah" yaitu pengikut-pengikut Dawud al Zahiri (w. $270 \mathrm{H}$ ) tak membenarkan adanya pentakwilan atau pengertian metaforis dalam teks-teks keagamaan, kecuali bila pengertian yang ditetapkan itu telah popular di kalangan orang-orang Arab pada masa turunnya Alquran, serta terdapat petunjuk yang jelas yang mendukung pengalihan makna atau penTakwi>lan tersebut. Lihat, Abu Zahrah, Ibn Hazm Haya >tubu> Wa 'As\} rubu (Cairo: Dar al-Fikr, tth.), h.226. 
(w. $270 \mathrm{H}$ ) yang dilanjutkan oleh Ibn $\mathrm{H}\{$ azm (w. $456 \mathrm{H}$ ), dalam kitabnya al- Muhalla. ${ }^{71}$ Kelompok ini juga menerapkan prinsip eksoterisme yang ketat dan cenderung menampilkan permusuhan yang ekstrem kepada intelektualisme, mistisisme, dan semua perbedaan sektarian yang ada dalam Islam. ${ }^{72}$

Dari keterangan di atas dapat dipahami bahwa istilah eksoterisme dalam mazhab fiqih adalah mereka yang menjadikan nashsh (teks) baik Alquran maupun hadits sebagai satu-satunya sumber otoritas yang sah. Merujuk pada pengertian eksoterik di atas, maka penulis menganalogikan bahwa dalam konteks penafsiran Alquran, kelompok eksoterisme adalah mereka yang menafsirkan ayat-ayat Alquran dari sudut pandang harfiah semata.

Dengan kata lain penafsiran mereka bertumpu pada makna tekstual-normatif dan menafikan sisi kontekstual-substantif dari ayatayat yang ditafsirkan tersebut. Hemat penulis, penyematan kata eksoteris ini berlaku secara umum. Tidak terbatas pada masa atau kelompok tertentu saja dalam sejarah penafsiran Alquran. Tegasnya, siapa saja, sejak masa klasik hingga kontemporer dewasa ini yang menafsirkan Alquran dengan hanya melihat sisi tekstual semata tanpa mengindahkan sisi konteks yang melingkupinya, maka itulah yang disebut dengan kelompok eksoterisme.

Pengertian esoterik menurut Nasr Hamid Abu Zaid yang lebih terperinci adalah makna yang berada di balik makna eksoteriknya, baik makna itu jumlahnya satu atau lebih; baik keterkaitannya dengan makna eksoterik dekat atau jauh, (untuk yang keterkaitannya jauh) diperlukan lintasan/jalan antara keduanya. ${ }^{73}$

${ }^{71}$ Makalah Ali Yafie, "Sistem Pengambilan Hukum oleh A'Immatu al-Madhahib", disampaikan pada Pusat Pengkajian Islam PPI-LPM UNINUS, 8 Februari 1988, sebagaimana dikutip oleh Jalaluddin Rahmat dalam Kata Pengantar buku Taufik Adnan Amal, Islam dan Tantangan Modernitas; Studi atas Pemikiran Hukum Fazlur Rabman (Bandung: Mizan, 1990), cet II, h. 20.

${ }^{72}$ Khaled Abu El- Fadl, Cita dan Fakta Toleransi dalam Islam; Puritanisme Versus Pluralisme (Bandung: Arrasy, 2003), h.24.

${ }^{73}$ Nasr Hamid Abu Zaid, Mafhum al-Nash (Bairut: Al-Markaz Al-Tsaqafi Al-Arabi, 1998) ,h.221 
Menurut pandangan Nasr Hamid Abu Zaid, Tafsir esoterik yakni upaya penggalian makna esoterik Alquran yang berada di balik makna eksoteriknya. Makna eksoterik yang dimaksudkan olehnya adalah makna yang nampak dari ayat (al-Ma'na al-Zhahir alBadi min al-Ayah). ${ }^{74}$

Di samping definisi di atas, Nasr Hamid Abu Zaid juga menjelaskan bahwa: (1) Batin ayat adalah makna tersiratnya;75 (2) Batin ayat adalah penakwilannya; ${ }^{76}$ (3) Batin adalah, di antaranya, makna ayat-ayat mutasyabih;77 (4) Tafsi>r esoterik diperuntukkan bagi kalangan khawwash atau elit saja, yang dipahami hanya dengan kasyf atau penglihatan batin melalui praktek kehidupan kerohanian; berlawanan dengan tafsir eksoterik, yakni mengungkap makna yang menyesuaikan diri pada tingkat pola dan pengertian pemikiran sederhana orang-orang awam. ${ }^{78}$ (5) Arti lahir Alquran adalah seperti lambang arti batinnya. Yakni, dalam ajaran-ajaran Allah yang berada di luar pemahaman orang kebanyakan terdapat bentuk-bentuk perumpamaannya, sehingga dapat dimengerti oleh mereka.

Proses penafsiran esoterik disebut takwil, yang secara teknis bermakna hermeneutika79 (hermeunetic) simbolis dan spiritual. Akan tetapi, secara etimologis, ia berarti membawa sesuatu kembali kepada

74 Nasr Hamid Abu Zaid, Mafbum al-Nash , h.221

75 Nasr Hamid Abu Zaid, Mafbum al-Nash, h.222.

${ }^{76}$ Nasr Hamid Abu Zaid, Mafbum al-Nash ,h. 223.

${ }^{77}$ Nasr Hamid Abu Zaid, Mafhum al-Nash,h. 223

${ }^{78} \mathrm{Nasr}$ Hamid Abu Zaid, Mafhum al-Nash, h.223

${ }^{79}$ Secara etimologis, kata hermeneutik berasal dari bahasa Yunani bermeneue yang dalam bahasa Inggris menjadi hermeneutics (to interpret) yang berarti menginterpretasikan, menjelaskan, menafsirkan, atau menerjemahkan. Dengan merujuk definisi yang dikemukakan, di antaranya, oleh Hosein Nasr, Zygmunt Bauman, dan Richard E. Palmer, dapat disimpulkan bahwa hermeneutik adalah disiplin filsafat yang berupaya menjelaskan, mengungkapkan, memahami, dan menulusuri pesan dan pengertian dasar yang mengejawentah dari suatu teks, wacana dan realitas, sehingga sampai kepada isi, maksud, dan makna terdalam (ultimate meaning) serta arti yang sebenarnya. Pada dasarnya hermeneutik berhubungan dengan bahasa. Kita berpikir, membuat interpretasi, berbicara, menulis dan lain sebagainyamelalui bahasa. (KomaruddinHidayat, Memahami Bahasa Agama Sebuah Kajian Hermeneutik (Jakarta: Paramadina, 1966); NazimNanji, "Toword a Hermeneutics of Qur'anic and Other Narratives of Isma'li Though", dalam Richard C. Martin, (Ed.), Approaches to Islam in Relegious Studies (Tucson: The University of Arizona Press, 1985); E. Sumaryono, Hermeuneutik SebuabMetode Filsafat (Yogyakarta:Kanisius, 1993); Salleh YaaparM.D., 'Takwil Sebuah Bentuk. Hermeneutik Islam, Ulum Al-Qur'an, Vol. III, No. 3 (Jakarta: Yayasan LSaf, 1992). 
awalnya, yaitu awal atau asal-usul; dengan demikian, membawa atau mengikuti simbol-simbol kembali kepada asal-usul yang dilambangkannya. Takwil berlaku untuk segala jenis simbol, baik di alam, dalam dunia manusia, maupun dalam teks wahyu. Alquran sendiri menggunakan kata ayat, tanda-tanda, atau isyarat-isyarat, untuk ayat-ayatnya sendiri serta untuk objek-objek dan peristiwaperistiwa di dalam dunia alam dan jiwa manusia. ${ }^{80}$

Menyangkut tafsir esoterik ini dan dengan merujuk kepada arti takwil yang berarti usaha mengembalikan sesuatu kepada asalnya, Seyyed Hossein Nasr menjelaskan bahwa memahami arti esoterik Alquran berarti mencapai asalnya, sebab asal inilah yang menjadi arti batin Alquran, sedangkan teksnya hanyalah bentuk lahir atau eksteriorisasi dari asal. Segala sesuatu datang dari "dalam" ke "luar", dari interior ke eksterior. Ia menjelaskan lebih lanjut:

We who live 'in the exterior' must return to the interior if we are to reach the Origin. Everything has an interior (bathin) and an exterior (zahir), and ta'wîl is to go from the zhahir to the bathin, from the external form to the inner meaning. The word phenomenon itself brings up the question 'of what', which implies the existence of a noumenon. Even Kant conceded the necessity of noumena but because he limited the intellect to reason he denied the possibility of our coming to know them. But when intellectual intuition is present and under the guidance of revelation one can penetrate the appearance to that reality of which the appearance is an appearance, one can journey from the exterior to the interior by this process of the ta'wîl, which in the case of the Quran means coming to understand its inner message. 81

Lebih jauh, Hussein Nasr melihat bahwa kisah tentang Mûsâ dan Khidhir, yang sering dikutip dalam sumber-sumber tradisional, melambangkan adanya arti esoterik Alquran. Khidhir-yang serupa dengan Elias dalam tradisi Kristen Yahudi-melambangkan esoterisme dan Mûsâ melambangkan eksoterisme hukum. Khidhir

\footnotetext{
${ }^{80}$ Seyyed Hossein Nasr, Ideals and Realities of Islam (London: George Allen \& Unwin Ltd, 1975), Cet. ke-2, h. 25.

81 Seyyed Hossein Nasr, Ideals and Realities of Islam, h.58-59.
} 
bersedia mengikutsertakan Mûsâ dalam perjalanannya bila tidak mengajukan pertanyaan-pertanyaan atas segala tindakannya. Segala tindakan Khidhir terlihat buruk dan membahayakan sehingga Mûsâ mencercanya. Akhirnya, Khidhir memutuskan untuk menghentikan perjalanan bersamanya, tetapi sebelumnya menjelaskan tujuan tersembunyi di balik segala tindakannya. Mûsâ, yang tidak mengetahui tujuan ini sebelumnya, akhirnya mengakui kesalahannya. Ini menunjukkan bahwa esoterisme mempunyai logika tersendiri, yang tidak dapat dijangkau dengan pendekatan eksoterik semata-mata. ${ }^{82}$

\section{Pustaka Acuan}

Abu Zaid, Nasr Hamid, Mafhum An-Nashsh, Bairut: Al-Markaz AlThaqafi Al-'Arabi, 1998

--------------, Al-Ittijah al-Aqli fi at-Tafsir : Dirasah fi qadliyyat alMajaz fi al-Qur'an Inda Mu'tazilah, Beirut: al-Markaz atsTsaqafi al-'Arabi, 1997.

Al-Khithab wa at- Ta'wil, Beirut: al-Markaz atsTsaqafi al-'Arabi, 2000.

-,al-Qaul al-Mufid fi Qadliyyat Abu Zaid, Kairo: Maktabah al-Madbuli, 1995.

,an-Nas as-Sult\}ah, al-Haqiqah; al-Fikr ad-Dini baina Iradat al-Ma'rifah wa Iradat al-Haimanah, Beirut: al-Markaz ath-Thaqafi al-Arabi, 1997

--------------,At-Tafkir fi Zaman at-Takfir: Dlid al-Jahl wa al-Zaif wa al-Khurafat, Kairo: Sina al-Nasyr, 1995.

-Falsafat at-Ta'wil: Dirasah fi Ta'wil al-Qur'an inda Muhyi ad-Din al-'Arabi, Beirut: Dar at-Tanwir li ath-Thaba'ah wa an-Nasyr, 1983.

------------,Ishkaliyat al-Qira'ah wa 'aliyyat at-Ta'wil, Beirut: Markaz al-Thaqafi, 1994 1992.

,Naqd al-Khithab ad-Dini, Kairo: Dar Sina li al-Nasyr,

${ }^{82}$ Seyyed Hossein Nasr, Ideals and Realities of Islam,h. 34. 
-------------, “The Textuality of The Koran", Islam and Europe in Past and Present, NIAS, 1997.

--------------,Pergolakan Politik dari Fundamentalis, Modernis hingga Post Modernis, Jakarta: Paramadina,1996

-----------,Islamic Spirituality Foundations , New York: Crossroad, 1991 ,Mu 'jizat Al-Qur'an, Bandung: Mizan, 1997 -,al-Fikr al-Islami: Qiraat Jadidah, Beirut: Markaz alInma' al-Qaumi, 1989.

'Abd Al-Hayy Al-Farmawi, Al-Bidayah fi Al-Tafsir Al-Maudu'i, Mesir: Al-Hadharah Al-'Arabiyah, 1977

Abd Al-Halim Najjar, Goldziher, Madhahib al-Tafsir al-Islami, Bairut: Dar Iqra', 1985

Al-Qanuji, ,Abjad al-Ulum al-Wasi al-Marqum fi Bayan Ahwal alUlum, Bairut: Da>r Al-Kutub Al-Ilmiyyah, 1978

al-Zarkashi, Al-Burhan fi 'Ulum al-Qur'an, Beirut: Da>r al-Ma'rifah, $1391 \mathrm{H}$

Arkoun, Muhammad, Berbagai Pembacaan al-Qur'an, terj. Machasin, Jakarta: INIS, 1997.

As-Suyuti, Jalaluddin 'Abd ar-Rahman, al-Itqan fi 'Ulum al-Qur'an, Kairo: Maktabah Dar at-Turath, 1983.

Azra, Azyumardi Konteks Berteologi di Indonesia;Pengalaman Islam, Jakarta: Paramadina,1999.

Baljon, J.M.S., Tafsir Qur'an Muslim Modern, ed. Ni'amullah Muidz, Jakarta: Pustaka Firdaus, 1991.

E. Sumaryono, Hermeuneutik SebuahMetode Filsafat, Yogyakarta: Kanisius, 1993.

Effendy, Bahtiar, Radikalidme Agama, Jakarta: PPIM IAIN, 1998.

Fahd ibn `Abd al-Rahman ibn Sulaiman al- Rumi, Ushul al-Tafsir wa Manahijuh, Riyadh, $1413 \mathrm{H}$.

Hanafi, Hassan. Al-Di>n wa ath- Thaurah, Vol VIII. Kairo: Maktabah Madbuli, 1981. 
------------, Dialog Agama dan Revolusi. edisi Indonesia dari Religious Dialogue And Revolution, terj. Tim Penterjemah Pustaka Firdaus. Jakarta: Pustaka Firdaus, 1994.

Hidayat, Komaruddin, Menafsirkan Kehendak Tuhan, Jakarta: Teraju, 2003.

----------,Memahami Bahasa Agama; Sebuah Kajian Hermeneutik. Jakarta: Paramadina, 1996.

Hidayatullah, Syarif. Diskursus Tafsir al-Qur'an Modern. Yogyakarta: Tiara Wacana, 1997.

Hossein Nasr, Seyyed Ideals and Realities of Islam,London: George Allen \& Unwin Ltd, 1975.

Hudgson, Marshall G.S. The Venture of Islam, Chicago and London: The University of Chicago Press, 1974.

Husain Al-Dhahabi, Muhammad al-Tafsir wa al-Mufassirun, Mesir:Dar al-Maktub al- Hadithah, 1976.

Kathir, Ibnu. Tafsir al-Qur'an al-'Azim. Beirut: Dar Ibn Hazm, 2000.

Kirk, Jarome \& Marc Miller, Reliability and Validity in Qualitative Research, Beverly Hill: Sage Publication: 1986.

Moeloeng,Lexy J Metodologi Penelitian Kualitatif, Bandung: PT Remaja Rosdakarya: 2007.

Muhammad 'Abd Al-'Azim Al-Zarqani, Manahil al-'Irfan fi 'Ulum alQur'an Beirut: Dar Al-Fikr, t.t.

Muhammad ibn Alawi Al-Maliki Al-Hasani, Zubdah al-Itqan fi 'Ulum al-Qur'an, Jeddah: Dar Al-Shuruq, 1983.

Mustaqim, Abdul Madhahibut Tafsir: Peta Metodologi Penafsiran al-Qur'an, Periode Klasik hingga Kontemporer, Yogyakarta: Nun Pustaka, 2003.

Ibn Hanbal, Imam Ahmad, Musnad al-Imam Ahmad Ibn Hanbal, Kairo: Matba'ah Mushthafa al-Bab al-Halabi, 1952.

Ibn Manzhur, Makram, Lisan al-Arab, Beirut: Dar ash-Shadir, 1993.

Ibn Taimiyah, Ah\}mad, Muqaddimah fi Ushul al-Tafsir, Kairo: Maktabah Al-Turath Al-Islami, t.t.. 
Ichwan, Moch.Nur, Meretas Kesarjanaan Kritis al-Qur'an, Jakarta: Teraju, 2003.

Imarah, Muhammad. al-Tafsir al-Markisi Li al-Islam. Kairo: Dar al-Shuruq, 1996.

Islambuli, Samir. Zahirat al-Nas al-Qur'an Tarich wa Mu'as\}irah. Damaskus: Da>r al-Awail, 2002.

Izzat Darwazah, Muhammad. al-Tafsir al-Hadith; Tartib al-Suwar Hasb al-Nuzul. Kairo: Dar al-Gharb al-Islami, 2000.

Mahmud, Mus\}tafa. Menangkap Isyarat al-Qur'an. Jakarta: Pustaka Firdaus, 1994.

Matsna, Moh. Orientasi Sematik al-Zamakhsyari. Jakarta: Anglo Media, 2006.

Ma'rifat, M. Hadi. Sejarah al-Qur'an. Jakarta: al-Huda, 2007.

Munawi, 'Abd. Al-Ra'uf. Faid al-Qadir; Sharh al-Jami' al-Saghir. Mesir: al-Maktabah al-Tijariyyah al-Kubra, $1356 \mathrm{H}$.

Muslim, Mustafa. Mabahith fi al-Tafsir al-Maudu'i. Damaskus: Dar al-Qalam, 1989.

Mustaqim, Abdul. Madhahib al Tafsir; Peta Metodologi Penafsiran al-Qur'an Periode Klasik Hingga Kontemporer. Yogyakarta: Nun Pustaka, 2003.

Mustaqim, Abdul, Sahiron Syamsuddin (ed.). Studi Al-Qur'an Kontemporer. Yogyakarta: PT. Tiara Wacana, 2002.

Nasir, Malki Ahmad. Hermeneutika Kritis (Studi Kritis atas Pemikiran Habermas, ISLAMIA,TI, No.I Maret 2004.

Nasution, Harun. Islam Ditinjau dari Berbagai Aspeknya. Jakarta: UI Press, 1985, Cet. Ke-5.

Nawawi, Rif'at Syauqi. Rasionalitas Tafsir Muh\}ammad Abduh; Kajian Masalah Akidah dan Ibadat. Jakarta: Paramadina, 2002.

Palmer, Richard. E. Hermeneutics: Interpretation Theory in Scheirmacher, Dilthey, Heidegger and Gadamer. Evanston: Nortwestern University Press, 1969.

Qutb, Sayyid. Islam The Religion of The Future. Delhi: Markazi Maktaba Islami, tth. 
---------. Fiqh al-Dakwah, Ahmad Hasan (ed), ttp: Muassasat ar-Risālah, 1970.

-------------. Keadilan Sosial dalam Islam, terj. Afif Muhammad, Bandung: Pustaka, 1984.

Fî Zhilāl al-Qur'ān. Beirut: Dār al-Syurūq, 1993, Cet. Ke-XXI, jilid I, II.

Rahman, Fazlur. Islam and Modernity: Transformation of an Intellectual Tradition. Chicago: The University of Chicago Press, 1984.

Metode dan Alternatif Neomodernisme Islam, terj. Taufik Adnan Amal. Bandung: Mizan, 1987.

---------. Tema Pokok Al-Qur'an, terj. Anas Mahyudin. Bandung: Pustaka, 1996, Cet. Ke-2.

Rahman, Yusuf "The Hermeneutical Theory Of Nasr Hamid Abu Zaid; An Analytical Study of His Method of Interpreting the Qur'an” Disertasi di McGill ,Montreal Canada: 2001.

Rahmat, Jalaluddin Ijtihad dalam Sorotan, Bandung: Mizan, 1998.

Richard C. Martin, (Ed.), Approaches to Islam in Relegious Studies ,Tucson: The University of Arizona Press, 1985

Rippin, Andrew (Ed.), Approaches to the History of the Interpretation of the Qur'an Oxford: Clarendon Press, 1988.

Robert D. Lee, Mencari Islam Autentik, terj. Ahmad Baiquni, (Bandung: Mizan, 2000).

Setiawan, Nur Kholis. al-Qur'an Kitab Sastra Terbesar. Yogyakarta: ELSAQ, 2005.

Sha'ban, Zakiy al-Din. Ushul al-Fiqh, Kairo: Dar al-Nashr, tth.

Shadily,Hassan. Ensiklopedi Indonesia. Jakarta, Ichtiar Baru-Van Hoeve, 1984.

Shihab, Quraish Membumikan Al-Qur'an, Bandung: Mizan, 1992

Shihab, Umar Kontekstualitas al-Qur'an; Kajian Tematik Atas Ayatayat Hukum dalam al-Qur'an Jakarta: Penamadani:2005. 